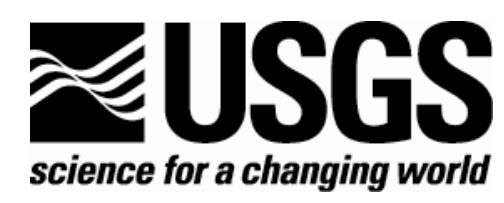

\title{
Biogenic Silica Measurements in Cores Collected from Bear Lake, Utah and Idaho
}

By Steven M. Colman and Jennifer W. Moore, U.S. Geological Survey, 384 Woods Hole Rd., Woods Hole, MA 02543

Katrina Moser, Dept. of Geography, University of Utah, Salt Lake City, UT 84102

Open-File Report 2005-1319

U.S. Department of the Interior U.S. Geological Survey 


\title{
U.S. Department of the Interior Gale A. Norton, Secretary
}

\section{U.S. Geological Survey \\ P. Patrick Leahy, Acting Director}

\author{
U.S. Geological Survey, Reston, Virginia 2005
}

For sale by U.S. Geological Survey, Information Services

Box 25286, Denver Federal Center

Denver, CO 80225

For more information about the USGS and its products:

Telephone: 1-888-ASK-USGS

World Wide Web: http://www.usgs.gov/

Any use of trade, product, or firm names in this publication is for descriptive purposes and does not imply endorsement by the U.S. Government.

Although this report is in the public domain, permission must be secured from the individual

copyright owners to reproduce any copyrighted material contained within this report.

This report has not been reviewed for stratigraphic nomenclature.

Suggested citation:

Colman, S.M., Moore, J.W., and Moser, K., 2005, Biogenic silica measurements in cores collected in Bear Lake, Utah and Idaho: U.S. Geological Survey Open-File Report 2005-1319, 10p.

\section{Prepared by the U.S. Geological Survey in Denver, Colorado}

(http://climchange.cr.usgs.gov/) 


\section{Biogenic Silica Measurements in Cores Collected in Bear Lake, Utah and Idaho}

By Steven M. Colman, Jennifer W. Moore, and Katrina Moser

\section{Introduction}

The overall goal of our research on Bear Lake is to create records of past climate change for the region, including changes in precipitation (rain and snow) patterns during the last 10,000 years and longer. As part of the project, we are attempting to determine how the size of Bear Lake has varied in the past in order to assess the possibility of future flooding and drought. We also seek to understand human influences on sediment deposition, chemistry, and life in the lake.

Evidence of past conditions comes from sediments deposited in the lake, so reconstructions of past conditions require accurate dating of the sediments. The study includes the upper Bear River watershed as well as Bear Lake. The Bear River is the largest river in the Great Basin and the source of the majority of water flowing into the Great Salt Lake. In this region, wet periods may produce flooding along the course of the Bear River and around Great Salt Lake, while dry periods, or droughts, may affect water availability for ecosystems, as well as for agricultural, industrial, and residential use.

Diatoms are one of the most sensitive indicators of environments in many lakes. In addition to species compositions and abundances (Moser and Kimball, 2005), total diatom productivity commonly varies considerably with changes in limnological conditions. Biogenic silica preserved in sediments is an index of total diatom productivity and, thus, is an indirect proxy for paleolimnology (for example, Colman and others, 1995; Johnson and others, 2001). In this paper, we present the results of biogenic silica analyses of two cores taken in Bear Lake, Utah, and discuss preliminary paleolimnologic conclusions based on these data.

\section{Methods}

\section{Coring}

Standard Kullenburg-type piston cores were obtained in September 1996 at three sites; BL96-1 (41.9527 $\left.{ }^{\circ} \mathrm{N}, 111.3160^{\circ} \mathrm{W}\right)$, BL96-2 $\left(41.9527^{\circ} \mathrm{N}, 111.3333^{\circ} \mathrm{W}\right)$ and BL96-3 $\left(41.9532^{\circ} \mathrm{N}, 111.3613^{\circ} \mathrm{W}\right.$ ) Utah (fig. 1). The cores ranged in recovered 


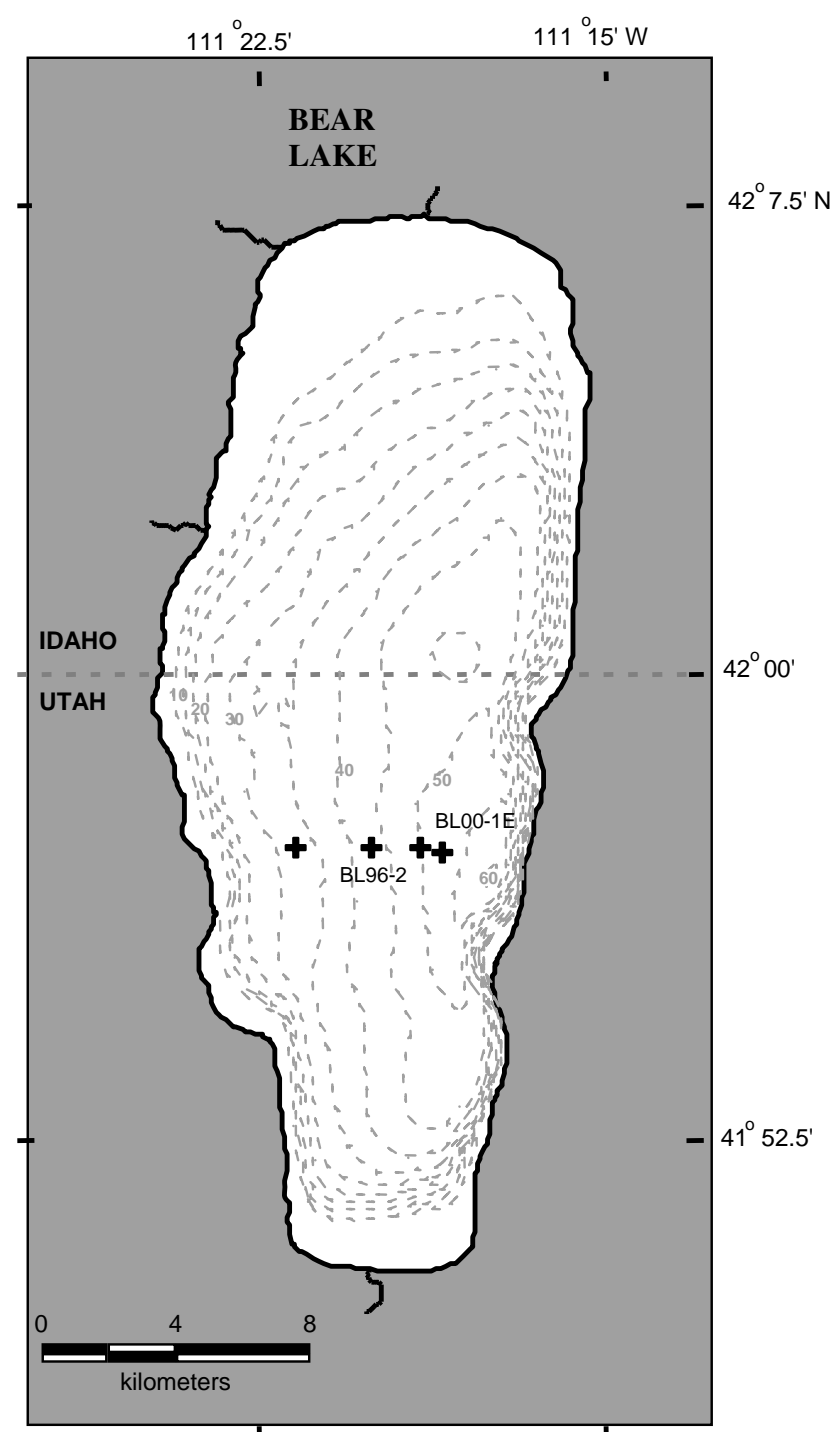

Figure 1. Map of Bear Lake showing the bathymetry of the lake and location of core sites; bold symbols are BL96-2 (west) and BL00-1E (east), discussed in detail here.

length from 4 to $5 \mathrm{~m}$ and were collected from a portable barge and coring system. The inner liner diameter of the plastic liner of these cores was $7 \mathrm{~cm}$. Samples from core BL96-2 were taken every $4 \mathrm{~cm}$ for biogenic silica analyses.

Two drill cores (BL00-1D and E), 100 to $120 \mathrm{~m}$ in length, were obtained near the site of BL96-1 (fig. 1). The upper section of the drill core was obtained by 7-cmdiameter, plastic lined, hydraulic piston core. The upper $10 \mathrm{~m}$ of drill core BL00-1E was sampled at 5-cm intervals for biogenic silica analyses.

Locations of the core sites were determined by standard GPS methods. 
Biogenic silica measurements

Biogenic silica sample digestions were performed using methods modified slightly from those of Mortlock and Froelich (1989) as described by Carter and Colman (1994). Hydrogen peroxide $\left(\mathrm{H}_{2} \mathrm{O}_{2}\right)$ and hydrochloric acid ( $\left.\mathrm{HCl}\right)$ solutions were added to samples to remove organic material and carbonate, respectively. Following these steps, $2 \mathrm{~N}$ sodium carbonate solution $\left(\mathrm{Na}_{2} \mathrm{CO}_{3}\right)$ was added to dissolve the biogenic silica within the sediment sample. Three milliliters of this solution were extracted from the sample, acidified, and analyzed by Inductively Coupled Plasma Atomic Emission Spectrometer (ICP-AES) for Si and Al. Raw (uncorrected) biogenic silica measurements were corrected for clay-mineral dissolution using measured aluminum values and an assumed Si:Al ratio of 2.0. This value, typical for montmorillonite (Carter and Colman, 1994), was used because of the absence of detailed chemical information for clays in Bear Lake sediments.

\section{Chronology}

Age models for the two cores discussed here were derived from radiocarbon ages determined for the three 1996 piston cores (Colman and others, 2005). For BL96-2, the age model of Colman and others (2005) was used directly (fig. 2). For the upper part of drill core BL00-1E, correlations were made between the two biogenic silica records (fig. 3) constrained by correlations based on seismic-reflection and magnetic susceptibility data (Colman, 2005).

\section{Results and Discussion}

Biogenic silica in Bear Lake sediments ranges from about 1.5 weight percent (15 mg/g) to a maximum of about $80 \mathrm{mg} / \mathrm{g}$ in the two cores studied (fig. 3). As such, biogenic silica represents a minor component of the overall sediment, but one which has major paleolimnologic implications. Changes in biogenic silica in the Bear Lake cores probably are due to the influence of climatic and hydrologic change on diatom productivity, although the exact linkage between the two is a complex issue. The complexities involve varied environmental tolerances of diatoms, nutrient availability and recycling, habitat availability and preservation, and recycling of diatom frustules.

Biogenic silica values are low during late glacial times (below $250 \mathrm{~cm}$ in BL96-2). In these intervals, actual diatom frustules are rare or absent (Moser and Kimball, 2005). The reason that biogenic silica values do not correspondingly go to zero is related to uncertainties in the correction (typically 3-8 mg/g in Bear Lake) made to the raw silica analyses to account for clay mineral dissolution during diatom digestion (Carter and Colman, 1994). Diatom productivity may have been limited by the cold and harsh conditions during and immediately following deglaciation (Wolfe, 2003). Diatom productivity also may have been low as a result of Si-limitation (Johnson and others, 2000). During this time, the Bear River was flowing into Bear Lake (Dean and others, 2005) and if this increased flow resulted in Bear Lake levels being sufficiently high, outflows may have removed much of the silica available for diatom growth. 


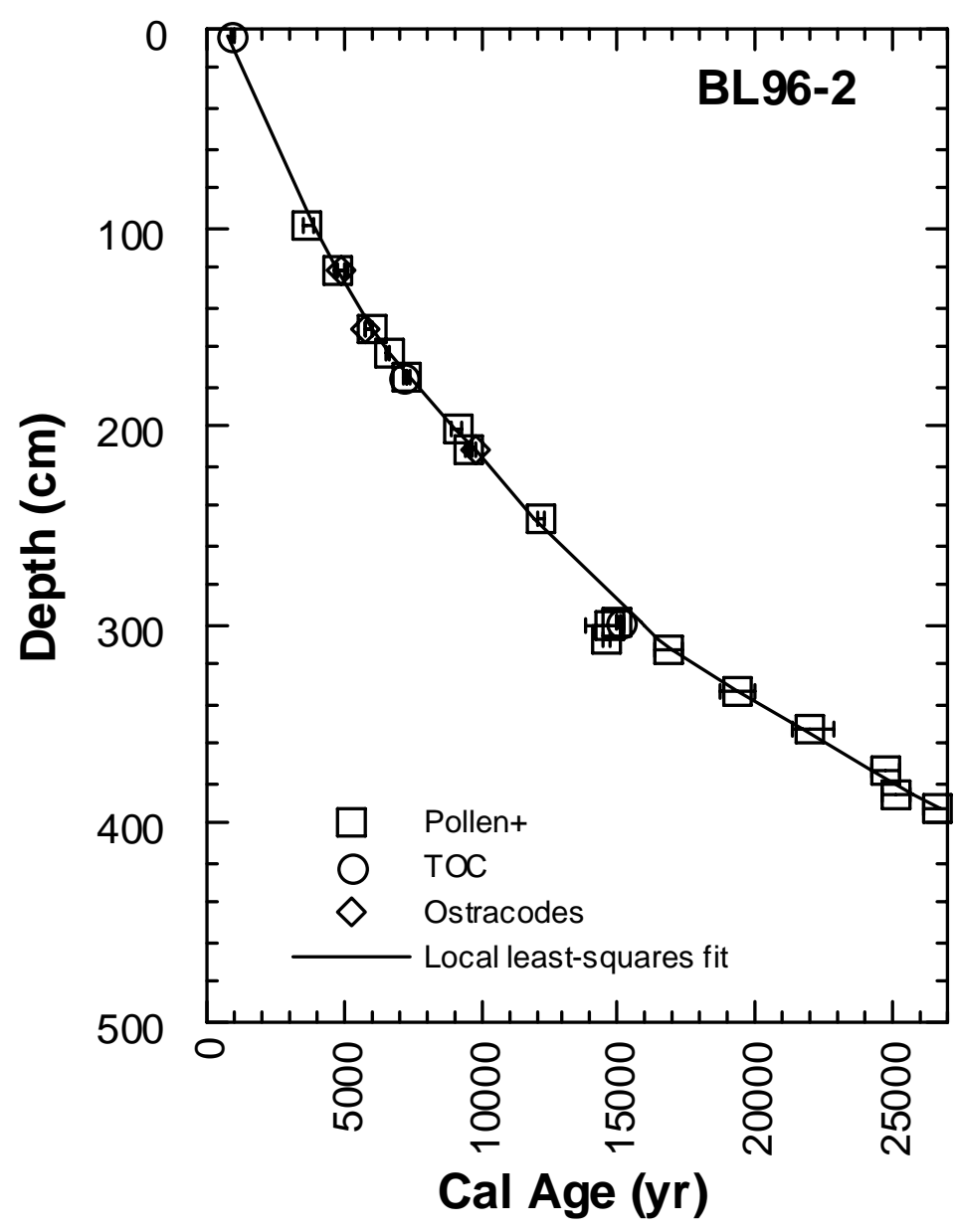

Figure 2. Age model for BL96-2 from Colman and others (2005).

Biogenic silica contents generally increase in postglacial sediments

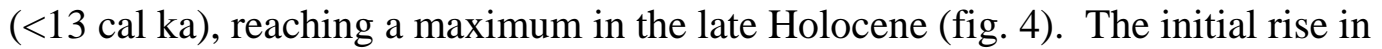
biogenic silica occurred when the Bear River ceased flowing into the lake (ca. $13 \mathrm{ka}$ ), suggesting that the increase in biogenic silica is less related to Si-limitation and more to ameliorating lake and climate conditions. During the Holocene, a number of fluctuations in biogenic silica content occur, and these fluctuations can be correlated between the two cores (figs. 3, 4). Prior to ca. 7.5 ka, lower values of biogenic silica correspond to increased abundances of planktonic diatoms and increased diatom diversity, which may relate to periods of increased stream inflow to Bear Lake and correspondingly higher lake levels (Moser and Kimball, 2005). During one of these peaks in planktonic diatoms, geochemical evidence suggests that Bear River returned to the lake for a brief time (ca. 9.5-7.5 ka) (Dean and others, 2005). 


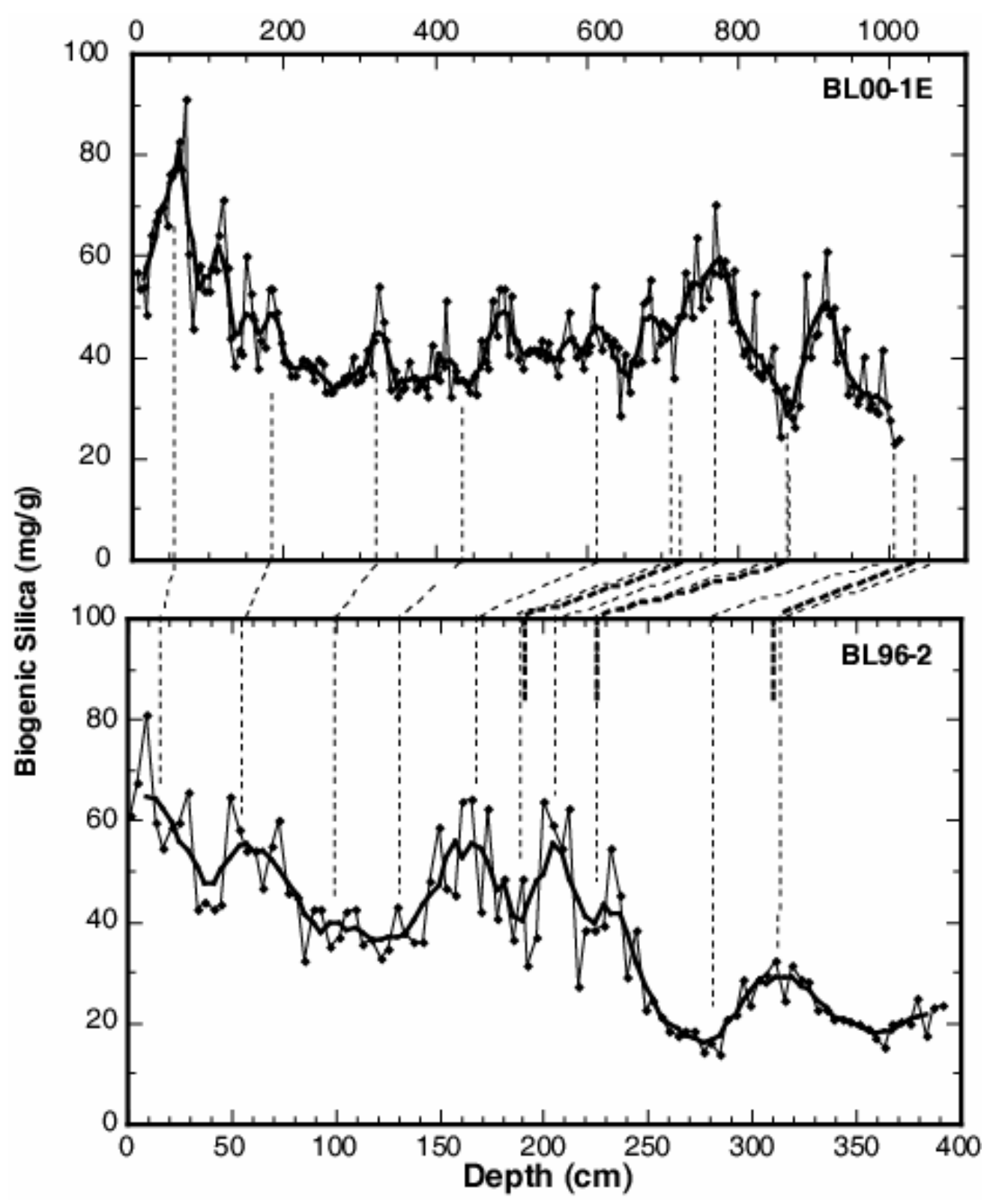

Figure 3. Plot of biogenic silica with depth for cores BL96-2 and the upper $10 \mathrm{~m}$ of BL00-1E. Heavy lines are five-point moving averages. Heavy dashed lines are correlations based on seismic reflections and magnetic susceptibility data (Colman, 2005); light dashed lines indicate inferred correlations of the biogenic silica records.

Fluctuations in biogenic silica content after 7.5 ka are strongly correlated to variations in diatom diversity and the abundance of Fragilaria brevistriata Grunow in Van Heurck. When diatom diversity is low and the abundance of Fragilaria brevistriata is high, biogenic silica is high. It has been suggested that increases in Fragilaria brevistriata are coincident with periods of lower effective moisture (Moser and Kimball, 2005). We observe that the Holocene record of diatom productivity is marked by a minimum of about $4-5 \mathrm{ka}$ (fig. 4), followed by a rise to maximum values in the late Holocene. 


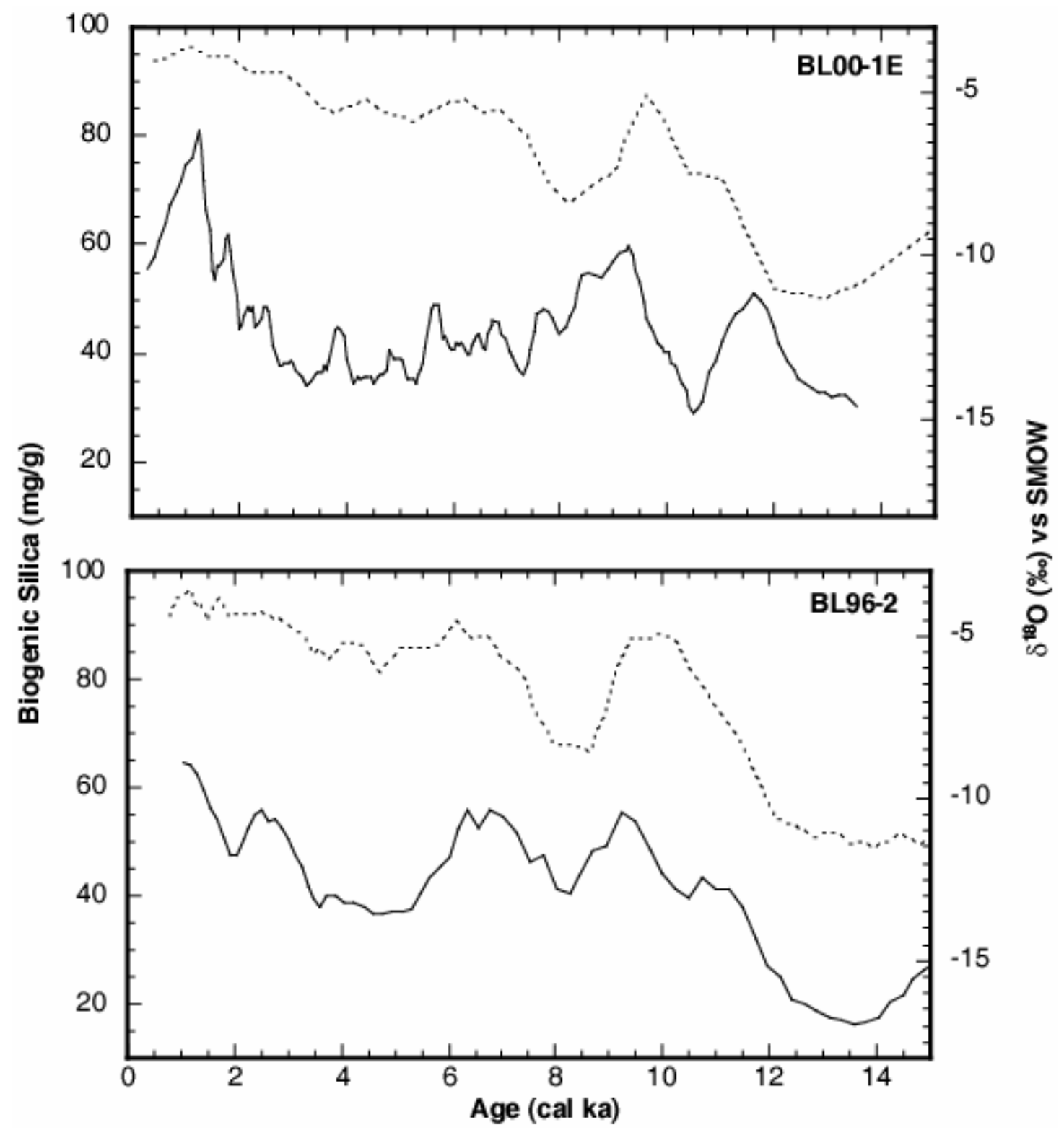

Figure 4. Plot of biogenic silica and oxygen isotope values with age for cores BL96-2 and the upper $10 \mathrm{~m}$ of BL00-1E. Biogenic silica data (solid line and left ordinate) are five point moving averages from figure 3; isotope data (dashed line and right ordinate) are from Dean and others (2005) (BL96-2) and Bright and others (in review) (BL00-1E). Age model for BL00-1E is based on the correlations shown in figure 3 and the age model for BL96-2 (fig. 2).

It is not entirely clear why drier conditions and lower lake levels in the late Holocene would result in increased productivity and decreased diversity, but inverse relations between these two variables previously have been noted (Stephens, 1998; Wolfe, 2003).

Biogenic silica values appear to correlate with oxygen isotope values of endogenic carbonate in the lake (fig. 4), indicating that higher isotope values 
correspond to higher diatom productivity. Higher (heavier) isotope values presumably result from greater evaporation and salinity in the lake, and these conditions appear to enhance diatom productivity.

\section{Conclusions}

Biogenic silica constitutes a minor constituent of Bear Lake sediments (maximum of about 8 percent), but one that provides important paleolimnologic information. The diatom assemblages that constitute the bulk of biogenic silica in the sediments change in response to a wide range of environmental variables (Moser and Kimball, 2005). Biogenic silica, as an indirect measure of total diatom productivity, also is an important environmental proxy. Diatom productivity was relatively low in glacial intervals and fluctuated from relatively high to intermediate values during the Holocene. Biogenic silica appears to correlate with heavy oxygen isotopes in carbonate, suggesting that diatoms were most productive when evaporation and the lake's dissolved solids were relatively high.

\section{References Cited}

Bright, J., Kaufman, D.S., Forester, R.M., and Dean, W.E., in review, A continuous 250,000 year record of oxygen and carbon isotopes in ostracode and bulksediment carbonate from Bear Lake, Utah-Idaho: Quaternary Science Reviews.

Carter, S.J., and Colman, S.M., 1994, Biogenic silica in Lake Baikal sediments: Results from 1990-1992 American cores: Journal of Great Lakes Research, v. 20, p. 751760.

Colman, S.M., 2005, Stratigraphy of lacustrine sediments cored in Bear Lake, Utah and Idaho, in 1996, U.S. Geological Survey Open-File Report 2005-1288.

Colman, S.M., Kaufman, D.S., Rosenbaum, J.G., and McGeehin, J.P., 2005, Radiocarbon dating of cores collected in Bear Lake, Utah, U.S. Geological Survey Open-File Report 2005-xxx.

Colman, S.M., Peck, J.A., Karabanov, E.B., Carter, S.J., Bradbury, J.P., King, J.W., and Williams, D.F., 1995, Continental climate response to orbital forcing from biogenic silica records in Lake Baikal, Siberia: Nature, v. 378, p. 769-771.

Dean, W.E., Forester, R.M., Colman, S.M., Liu, A., Skipp, G., Simmons, K.R., Swarzinski, P., Anderson, R., and Thornburg, D., 2005, Modern and glacialHolocene carbonate sedimentation in Bear Lake, Utah-Idaho, U.S. Geological Survey Open-File Report 05-1124.

Johnson, T.C., Barry, S.L., Chan, Y., and Wilkinson, P., 2001, Decadal record of climate variability spanning the past $700 \mathrm{yr}$ in the southern tropics of East Africa: Geology, v. 29, p. 83-86.

Johnson, T.C., Kelts, K., and Odada, E., 2000, The Holocene history of Lake Victoria: Ambio, v. 29, p. 2-11.

Mortlock, M.A., and Froelich, P.N., 1989, A simple method for rapid determination of biogenic opal in pelagic marine sediments: Deep-Sea Research, v. 36, p. 14151426.

Moser, K.A., and Kimball, J.P., 2005, Diatom analysis of Bear Lake Cores 96-1, 96-2, and 98-10, U.S. Geological Survey Open-File Report 2005-xxx. 
Stephens, D.W., 1998, Salinity-induced changes in the aquatic ecosystem of Great Salt Lake, Utah, in Pitman, J., and Carroll, A., eds., Modern and Ancient Lake Systems: New Problems and Perspectives, Utah Geological Association Handbook 26.

Wolfe, A.P., 2003, Diatom community responses to late-Holocene climatic variability, Baffin Island, Canada: A comparison of numerical approaches: The Holocene, v. 13, p. 29-37. 